Article

\title{
On Sound: Reconstructing a Zhuangzian Perspective of Music
}

\section{So Jeong PARK}

Received: 15 September 2015; Accepted: 19 December 2015; Published: 28 December 2015

Academic Editor: Albrecht Classen

Chinese/Philosophy, Nanyang Technological University, 14 Nanyang Drive, HSS-03-16, Singapore 637332; sjpark@ntu.edu.sg; Tel.: +65-6790-6707

\begin{abstract}
A devotion to music in Chinese classical texts is worth noticing. Early Chinese thinkers saw music as a significant part of human experience and a core practice for philosophy. While Confucian endorsement of ritual and music has been discussed in the field, Daoist understanding of music was hardly explored. This paper will make a careful reading of the Xiánchí 咸池 music story in the Zhuangzi, one of the most interesting, but least noticed texts, and reconstruct a Zhuangzian perspective from it. While sounds had been regarded as mere building blocks of music and thus depreciated in the hierarchical understanding of music in the mainstream discourse of early China, sound is the alpha and omega of music in the Zhuangzian perspective. All kinds of sounds, both human and natural, are invited into musical discourse. Sound is regarded as the real source of our being moved by music, and therefore, musical consummation is depicted as embodiment through sound.
\end{abstract}

Keywords: music; sound; philosophy; ritual and music; Zhuangzi; Xiánchí music

\section{Introduction}

It is doubtful whether music can be made the subject of philosophy. Philosophy is fundamentally based on reason, whereas the history of music has been regarded as a history of human passion, at least in Western thought. For the very same reason, some thinkers regard music as the purest art form or as an antidote to philosophy. This whole discourse would have been strange to early Chinese thinkers, who did not see any struggle between philosophy and music, but rather saw music as a core practice for philosophy.

Among those thinkers, Zhuangzi ${ }^{1}$ has a unique position. He might have seen music as a significant part of human experience, like the other thinkers of the pre-Qin period, but he also attempted to expand the musical domain beyond something that would be only meaningful in human society ${ }^{2}$. This suggestion was handed down to a follower who wrote the story of the Xiánchí 咸池 music appearing in the Outer Chapters of the Zhuangzi, which is a detailed and careful criticism of what was then mainstream musical discourse. While sounds had been regarded as mere building blocks of music and thus depreciated in the hierarchical understanding of music, sound is the alpha and omega of music in the Zhuangzian perspective. If Zhuangzi invites all kinds of sounds, both human and natural, into musical discourse, the author of the Xiánchí music story goes one step further to show that any musical consummation is expressed through sound and that embodied musical sound is the real source of our being moved by music.

1 This paper follows the custom of calling the presumed author of the Inner Chapters of the Zhuangzi as Zhuangzi. The Outer Chapters, where Xiánchí music story appears, is regarded as an anthology of Zhuangzian schools. As for the textual analysis of the Inner Chapters and other chapters of the Zhuangzi, see [1].

2 As for the general views on music in the Zhuangzi, see [2]. 
In this paper, I will give a close reading of the discussion of Xiánchí music ${ }^{3}$. In doing so, I explore: (1) how a Zhuangzian view embraces yet surpasses the musical discourse of the time; (2) what alternatives are proposed in musical expression and structure; and (3) what kinds of aesthetic feelings are likely to be aroused according to variations of musical sounds.

Before having a closer look, I should explain my approach to the basic structure of Xiánchí music and its key phrases in progression. Xiánchí music is in the following format: for Northgate Chéng, who was stunned by the music, Yellow Emperor divides it into three movements and explains a way of performance, musical expression and feelings that would be aroused by the music at each movement. The structure of Xiánchí music bears a resemblance to those of the stories of Heavenly piping (tiānlài, 天 籟), Cook Dīng (páodīngiiěniú, 庖丁解牛), the fasting of the mind (xīnzhāi, 心齋) and complete forgetting (zuowang, 坐忘) in the Inner Chapters of the Zhuangzi, in that it embodies the process of reaching Dao with three steps (Table 1). If the author of Xiánchí music intended it, there must be a progression from the first to the last movement ${ }^{4}$.

Table 1. Three steps for achieving Dao in the Xiánchí music story and the Inner Chapters.

\begin{tabular}{|c|c|c|c|}
\hline 《莊子. 天運》 5 & The First Movement & The Second Movement & The Third Movement \\
\hline \multirow{2}{*}{$\begin{array}{l}\text { Chéng's Emotional } \\
\text { Responses }\end{array}$} & 始聞之懼 & 復聞之怠 & 卒聞之而惑 \\
\hline & Terrified & Exhausted & Confused \\
\hline \multirow{2}{*}{$\begin{array}{l}\text { (Part 1) } \\
\text { Yellow Emperor's } \\
\text { Performance }\end{array}$} & $\begin{array}{l}\text { 吾奏之以人, 徽之以天, } \\
\text { 行之以禮義, 建之以太清. }\end{array}$ & $\begin{array}{c}\text { 吾又奏之以陰陽之和， } \\
\text { 燭之以日月之明 }\end{array}$ & $\begin{array}{l}\text { 吾又奏之以无怠之聲, } \\
\text { 調之以自然之命 }\end{array}$ \\
\hline & $\begin{array}{l}\text { Performed with human and } \\
\text { heaven; ritual principle and } \\
\text { great clarity }\end{array}$ & $\begin{array}{l}\text { Performed with the harmony } \\
\text { of Yin and Yang; the shining } \\
\text { of the Sun and the Moon }\end{array}$ & $\begin{array}{l}\text { Performed with } \\
\text { non-exhausting sounds; } \\
\text { tuned it to a scale of } \\
\text { spontaneity }\end{array}$ \\
\hline \multirow{4}{*}{$\begin{array}{l}\text { (Part 2) } \\
\text { Musical Expression } \\
\text { and Musical } \\
\text { Structure }\end{array}$} & $\begin{array}{l}\text { 一盛一衰, 一清一濁 } \\
\text { 一死一生,一僨一起 }\end{array}$ & 其聲能短能長，能柔能剛 & $\begin{array}{l}\text { 或謂之死, 或謂之生, } \\
\text { 或謂之實, 或謂之榮 }\end{array}$ \\
\hline & Now A, Now $\sim A$ & Can be A, Can be $\sim \mathrm{A}$ & $\begin{array}{l}\text { Some deem } \mathrm{A}, \\
\text { Some deem } \sim \mathrm{A}\end{array}$ \\
\hline & 所常无窮 & 不主故常 & 不主常聲 \\
\hline & $\begin{array}{l}\text { Their constancies } \\
\text { alternate unendingly }\end{array}$ & $\begin{array}{l}\text { Not bounded by any } \\
\text { preceding constancy }\end{array}$ & $\begin{array}{l}\text { Not bounded by any } \\
\text { constant sounds }\end{array}$ \\
\hline \multirow{2}{*}{$\begin{array}{c}\text { (Part 3) } \\
\text { Chéng's Receptions } \\
\text { Rephrased by Yellow } \\
\text { Emperor }\end{array}$} & 而一不可待. 汝故懼也 & $\begin{array}{l}\text { 子欲慮之而不能知也 ... 形充 } \\
\text { 空虛, 乃至委蛇. 汝委蛇, 故急 }\end{array}$ & $\begin{array}{c}\text { 世疑之, 稭於聖人... 此之 } \\
\text { 謂天樂. 汝欲聽之而無接焉， } \\
\text { 而故惑也. }\end{array}$ \\
\hline & $\begin{array}{l}\text { Terrified: nothing can be } \\
\text { counted on }\end{array}$ & $\begin{array}{l}\text { Exhausted: moving along } \\
\text { with changes }\end{array}$ & $\begin{array}{l}\text { Confused: wanting to listen, } \\
\text { but no way to go about it }\end{array}$ \\
\hline \multirow{2}{*}{$\begin{array}{l}\text { Yellow Emperor's } \\
\text { Final Comments on } \\
\text { Chéng's Emotion }\end{array}$} & 樂也者, 始於懼, 懼故崇 & $\begin{array}{l}\text { 吾又次之以怠, } \\
\text { 怠故遁 }\end{array}$ & $\begin{array}{c}\text { 卒之於惑,惑故愚, 愚故道, } \\
\text { 道可載而與之俱也 }\end{array}$ \\
\hline & Being stunned & Being compliant & Being stupid toward Dao \\
\hline \multirow{2}{*}{$\begin{array}{l}\text { 《莊子. 齊物論》6 } \\
\text { Chapter 2, } \\
\text { Inner Chapters }\end{array}$} & 人籟: 比竹 & 地籟: 衆憿 & $\begin{array}{l}\text { 天籟: 吹萬不同, 而使其自己 } \\
\text { 也，咸其自取，怒者其誰邪 }\end{array}$ \\
\hline & Humanly piping & Earthly piping & Heavenly piping \\
\hline
\end{tabular}

3 As the source of the Xiánchí music text, I use [3], which includes Guo Xiang (晉. 郭象) and Cheng Xuan-ying's (唐. 成玄英) commentaries. My discussion of other traditional commentaries is based on $[4,5]$.

4 It is controversial whether the three steps mean three movements of a musical suite, or a performance of one song three times repeated, or three different types of music. Here, I would like to introduce the first, second and the final movement into the text. Although the music might not have a systematic musical structure, such as a modern musical form, there are reliable grounds for that: e.g., [3] Cheng Xuan-ying's commentary in Chapter 3 "Jingshǒu is the name of a movement of Xiánchí (經首, 咸池樂章名)”。

5 This is the fourteenth chapter of the Zhuangzi, the title of which renders into "The Turnings of Heaven". I use [3-5] for the Chinese text of Xiánchí music.

6 This is the second chapter of the Zhuangzi, the title of which renders into "Discussion on Making All Things Equal". As for Heavenly piping story, refer to [3]. 
Table 1. Cont.

\begin{tabular}{|c|c|c|c|}
\hline 《莊子. 天運》 & The First Movement & The Second Movement & The Third Movement \\
\hline \multirow{2}{*}{$\begin{array}{c}\text { 《莊子. 養生主》 } 7 \\
\text { Chapter 3, } \\
\text { Inner Chapters }\end{array}$} & $\begin{array}{l}\text { 始臣之解牛之時, } \\
\text { 所見无非全牛者 }\end{array}$ & 三年之後, 未嘗見全牛也 & $\begin{array}{l}\text { 臣以神遇而不以目視,官知 } \\
\text { 之而神欲行. 依乎天理... } \\
\text { 十九年而刀刃若新發於研 }\end{array}$ \\
\hline & $\begin{array}{l}\text { First time: looking at the } \\
\text { object with one's eyes }\end{array}$ & $\begin{array}{l}\text { Three years later: seeing } \\
\text { through the object in mind }\end{array}$ & $\begin{array}{l}\text { Nineteen years later: } \\
\text { meeting the object by } \\
\text { one's spirit }\end{array}$ \\
\hline \multirow{2}{*}{$\begin{array}{l}\text { 《莊子. 人間世》8 } \\
\text { Chapter } 4, \\
\text { Inner Chapters }\end{array}$} & 若一志, 无聽之以耳 & $\begin{array}{l}\text { 聽之以心, } \\
\text { 无聽之以心 }\end{array}$ & $\begin{array}{c}\text { 聽之以氣! ... 氣也者, } \\
\text { 虛而待物者也. } \\
\text { 唯道集虛. 虛者, 心齋也 }\end{array}$ \\
\hline & Senses & Mind & Qi Fasting Mind \\
\hline \multirow{2}{*}{$\begin{array}{l}\text { 《莊子. 大宗師》9 } \\
\text { Chapter 6, } \\
\text { Inner Chapters }\end{array}$} & 忘禮樂（仁義） & 忘仁義（禮樂） & 坐忘 \\
\hline & Forgetting social customs & Forgetting internal morality & Forgetting self \\
\hline
\end{tabular}

For a detailed discussion, I analyze Yellow Emperor's explanation of each movement into different parts, namely, the parts of the musician's performance, the musical expression and the listener's reception, as seen in Table 1. The reason for distinguishing between them, even though a player's performance and the musical content expressed by it may not nicely separate in reality, is the convenience in figuring out a detailed structure of Xiánchí music. In doing so, we can find the parallel phrases to go through in each movement, and thus, the author's intention becomes clearer. The part of Yellow Emperor's "performance" summarizes a basic direction of the performance designed in each movement; the second part "musical expression" shows how each movement musically unfolds in progression; the part of a listener's "reception" rephrases what the emotional responses to each movement are like and why Chéng unexpectedly felt in those ways. Their dialogue is composed of three steps, as we can see in the Inner Chapters. As it progress, it moves further away from Confucian constructive terminology toward Daoist deconstructive vocabulary and from intentional variation toward spontaneous playing.

Where we can find distinctive musical developments between the three movements is the second "musical expression" part. Firstly, a parallel of musical structure is found, which is a progression from the "now $\mathrm{A}$, now $\sim \mathrm{A}$ " formation in the first movement to "can be made $\mathrm{A}$, can be made $\sim \mathrm{A}$ " in the second and to "some call A, some call $\sim \mathrm{A}$ " in the last. All of these formations constitute the interplay of opposites. They are designed in a way of alternately coming and going between opposites, such as flourishing and declining, clear and turbid, dead and alive, falling and rising, short and long, yielding and strong, fruit and flower. Secondly, these parallels are summarized into more general statements which are all related to "constancy" in music: from "their constancies alternate unendingly", through "not bounded by any preceding constancy"10, to "not bounded by any constant sounds." In what follows, I will first show the full text of Xiánchí music and examine a series of progression from the first to the final movement.

7 This is the third chapter of the Zhuangzi, the title of which renders into "The Secret of Caring for Life". As for Cook Dīng story, refer to [3].

8 This is the fourth chapter of the Zhuangzi, the title of which renders into "In the World of Men". As for Fasting Mind story, refer to [3].

9 This is the sixth chapter of the Zhuangzi, the title of which renders into "The Great and Venerable Teacher". As for Complete Forgetting story, refer to [3].

10 The second statement, viz. "bùzhŭ gùcháng", takes root in Chinese literary criticism as a technical term for unconventional style without formality or an attitude of being free from worldly cares. 


\section{Textual Research on Xiánchí Music ${ }^{11}$}

This is the opening of Xiánchí music. It begins with the questioning of Chéng of Northgate.

Chéng of Northgate asked the Yellow Emperor, "When I heard that Your Majesty performed the Xianchi music in the wilds of Dongting, I was at first terrified. As it continued, I felt exhausted, and by the end I was in a total confusion-like drifting endlessly and being dumbstruck ${ }^{12}$, I couldn't get hold of myself."

北門成問於黃帝曰: “帝張咸池之樂於洞庭之野, 吾始聞之懼, 復聞之怠, 卒聞之而惑; 蕩蕩默 默, 乃不自得."

\subsection{The First Movement of Xiánchí Music}

Yellow Emperor commences his explanation with sympathy for Chéng's emotional experience in extreme turbulence.

"I should think you would," said the emperor.

帝曰: “汝殆其然哉!”

\subsubsection{Performance in the First Movement}

I performed it through the Human, but also tuned it to the Heaven, advancing it with ritual principle ${ }^{13}$, but rooting it with the Great Clarity.

吾奏之以人, 徽之以天, 行之以禮義, 建之以太清.

\{For Most perfect music responds to human affairs but also accords with the natural pattern; proceeded by the Five Virtues, but also accorded with the Spontaneity. Only then can it bring order to the four seasons and bestow a final harmony upon the ten thousand things. $\}^{14}$

\{夫至樂者, 先應之以人事, 順之以天理, 行之以五德, 應之以自然, 然後調理四時, 太和萬物.\}

Then, he moves on musical content, which at first made Chéng terrified.

\subsubsection{Musical Expression in the First Movement}

It shows the four seasons arise in succession; the myriad things are born in sequence. Now flourishing, now declining, the soft and the tough alternate with each other; Now clear tone, now turbid tone, yin and yang adjust to each other.

四時迭起, 萬物循生. 一盛一衰, 文武倫經;一清一濁, 陰陽調和.

The sound then flows and radiates like hibernating insects that begin to stir in spring and I startle them with the crash of thunder, but there is no conclusion at the end and no

11 The translations are mine, but I have consulted [6-8], the translations of Watson, Mair and Ziporyn. I am also indebted to a discussion with Brook Ziporyn and Franklin Perkins at Nanyang Technological University, Singapore, in 2012 autumn.

12 Examining [3] and [4], the traditional commentaries varied in their interpretations for "dàngdàng 蕩蕩" and “mòmò 默默" Cheng Xuan-ying (Tang Dynasty, mid-Seventh Century) regards both as describing Chéng's experiences on the final step, viz. the state of confusion (huo 惑), explaining respectively “being flat and plain 平易” and “being ignorant 無知." Luo Mian-dao (明. 羅勉道 Yuan to Ming Dynasty, mid-Fourteenth Century) and Xuan Ying (清. 宣穎 Qing Dynasty, early Eighteenth Century) renders them into “his spirit cannot concentrate anywhere (神不定/神不能定)" and “his mouth cannot say any words (口不言/口不能言).” As I understand it, these descriptions are two sides of the state of losing self: turning his eyes outside, it is as if something is boundlessly extended, and his spirit has no place to focus on; his eyes inside, it is as if he himself is totally ignorant, and there is nothing to say.

13 Liyi 禮義 is translated into "ceremony and righteousness" in [7] and "trappings of Ritual and Responsibility" in [8] as paralleled compound words with two characters on equal footing. However, liyi appears in the Xunzi and the Book of Music as a compound term. Considering the connection between the Xiánchí story and the Book of Music and also the composition of its parallel, "Great Clarity," I translate it into "ritual principle".

14 These 35 characters are regarded as misplaced commentaries. See ([9], p. 210). 
prelude at the beginning. Now dead, now alive; now falling, now rising, their constancies alternate unendingly.

流光其聲, 蟄蟲始作, 吾驚之以雷霆, 其卒无尾, 其始无首. 一死一生,一僨一起, 所常无窮.

As we see in Table 2, the first movement borrows many terms and phrases, which are uniquely used in the Book of Music (yueji, 樂記) ${ }^{15}$, and this tendency is completely dismissed after the phrase "there is no conclusion"; then, similar terms and ideas in Confucian musical discourses are never used again in the second and the final movement ${ }^{16}$. The overwrapping in terms is too frequent for it to be a coincidence. I will further discuss the probable purpose of this usage and its significance in the later section.

Table 2. Related passages in the Book of Music to the first movement of Xiánchí music ${ }^{17}$.

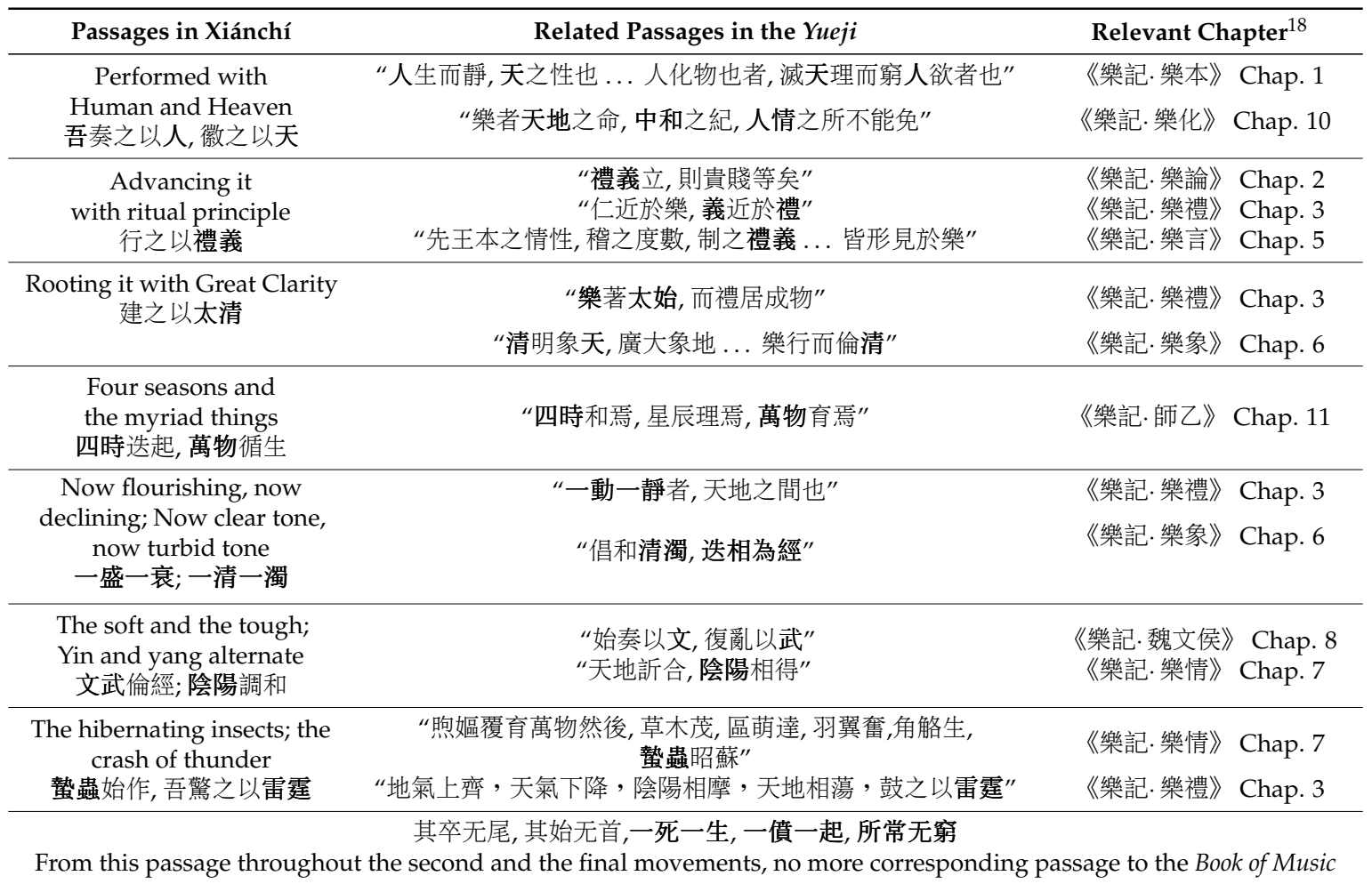

\subsubsection{Reception in the First Movement}

There is nothing that can be counted on. That's why you felt terrified.

而一不可待, 汝故懼也.

15 As for the original text of the Book of Music, I mainly used [10] and [11]. I refer to [12] for the English translation.

16 Fukunaga first pointed out that the musical terminology used in the first movement is mostly that of the Book of Music. See [13], p. 133). He indicated that, except for yinnyáng 陰陽, which is a neutral term, the terms, such as "ritual principle (liyì)," "four seasons (sìshí)," "ten thousand things (wànwù)" and "the civil and military strains (wénwŭ)," in this first movement are Confucian-friendly terms.

17 Xiánchí appears in Chapter 4 “Yueshi 樂施” of the Book of Music: “《咸池》, 備之也”, the Zhouli 周禮, “Dasiyue 大司樂”: “大 司樂... 以樂舞教國子,舞雲門、大卷、大咸..." and the Lüshì Chünqiū.

18 We can see that Xiánchí music widely and thoroughly makes a reference to the Book of Music. The related concepts and passages stretch over most chapters of the Book of Music, except for Chapter 9, which contains a specific description and discussion on $W u$ 武 music. Chapter 4 does not seem to have exactly overlapped passages, but directly mentions "Xiánchí" as mentioned before. 


\subsection{The Second Movement of Xiánchí Music}

\subsubsection{Performance in the Second Movement}

Then I performed it with the harmony of yin and yang, brightened it with the shining of sun and moon.

吾又奏之以陰陽之和, 燭之以日月之明 19 .

\subsubsection{Musical Expression of the Second Movement}

The sound can be made short or long, yielding or strong, it impartially modulates but is not bounded by any preceding constancy.

其聲能短能長, 能柔能剛; 變化齊一, 不主故常.

Coming to a valley, it fills the valley; coming to a pit, it fills the pit. Fitting any crevice, it yet maintains its spirit; taking on the measure of each thing it encounters.

在谷滿谷, 在阬滿阬; 塗卻守神, 以物为量.

The sound is undulated and lilted, the rhythm ${ }^{20}$ is lofty and bright, and thus, the ghosts and spirits rest in their darkness, the sun, moon, stars, and constellations march in their orbits. I made it stop where there is an end to things but also let it flow where there is no limitation.

其聲揮綽, 其名高明, 是故鬼神守其幽, 日月星辰行其紀. 吾止之於有窮, 流之於無止.

\subsubsection{Reception in the Second Movement}

You try to fathom it but fail to understand; try to gaze at it, but fail to see; try to chase after it but fail to catch it.

予欲慮之而不能知也, 望之而不能見也, 逐之而不能及也.

You, as if disorientedly standing in the way opened to all directions, lean against a withered tree and moan.

儻然立於四虛之道, 倚於槁梧而吟.

Your eyes are exhausted by wanting to see, your strength is expended by wanting to pursue it. It is nothing yourself can do anything about.

目知窮乎所欲見, 力屈乎所欲逐, 吾既不及已夫!

Your body is filled with emptiness, and this brought you to be moving along with changes ${ }^{21}$. Moving along with all sorts of changes, you feel exhausted.

形充空虛, 乃至委蛇. 汝委蛇, 故急.

19 With a few exceptions, such as yīnyáng 陰陽 and rìyùe 日月, appearing in the Book of Music, the second and the final movements of the Xiánchí music story are mainly filled with the unique expressions of Daoist musical discourse, which cannot be found in any other musical literature.

20 I render “ming 名” into "rhythm" according to Lin Yun-ming (清. 林雲銘), a Qing commentator, "rhythm can be named or symbolized (節奏之可名象者)." Mair puts it as "cadence".

21 As for "wēiyí 委蛇", Watson translated it into "an idle freedom," Mair "indifferent" and Ziporyn "serpentine changes", respectively. However, in Chapter 7 of the Zhuangzi, “委蛇” is used as an adjective by which Huzi (瑴子) describes his own movement of following Dao, which literally means "meandering like the traces which is created as a snake windingly passes by". “Weìiý” is used as an adjective also in the Book of Odes (詩經: 國風.召南·羔羊): “委蛇委蛇”. 


\subsection{The Final Movement of Xiánchí Music}

\subsubsection{Performance in the Final Movement}

And then I performed with non-exhausting sounds, tuned it to a scale of spontaneity ${ }^{22}$. 吾又奏之以無怠之聲, 調之以自然之命.

\subsubsection{Musical Expression of the Final Movement}

Thus the sounds are born in clusters, mingling and chasing each other as like a forest of bells ${ }^{23}$ without form; they are spread around where nothing gets pulled as like a clouded obscurity without sound.

故若混逐叢生, 林樂而無形; 布揮而不曳, 幽昏而無聲.

It moves in no direction at all, it rests in mysterious shadow ${ }^{24}$. Some would call it death, some would call it life; some would call it fruit, some would call it flower. The music is moving, flowing, scattering, and shifting, not bounded by any constant sounds.

動於無方, 居於窈冥; 或謂之死, 或謂之生; 或謂之實, 或謂之榮; 行流散徙, 不主常聲.

Contrary to the other two movements, there are two kinds of responses in the final movement: one is the general reception of the world, and another is the personal feeling of Chéng. It likely suggests that Chéng is not the only person who felt confusion after listening to Xiánchí music, but that anyone who heard it would be perplexed. Therefore, the emotions that Chéng gradually felt are not just personal appreciation, and Xiánchí music is not a mystic teaching for hermits, but a Zhuangzian point of view on music for the world.

\subsubsection{Reception of the World in the Final Movement}

The world is perplexed by it and can only query the sage, for the sage is one who comprehends the genuine emotion ${ }^{25}$ and completes one's own destiny ${ }^{26}$.

世疑之, 稽於聖人. 聖也者, 達於情而遂於命也.

The natural mechanism is not triggered yet but all the bodily organs are intact. This is called Heavenly joy, which Heavenly music brings about ${ }^{27}$. Wordless, it delights the heart. 天機不張而五官皆備, 此之謂天樂, 無言而心説.

Therefore the lord of Yen ${ }^{28}$ sang a eulogy of it, saying “Listening for it, I don't hear its sound; looking for it, I don't see its shape, but it fills heaven and earth, encompasses the world's outermost limits."

故有炎氏之頌曰: “聽之不聞其聲, 視之不見其形, 充滿天地, 苞裹六極.”

22 The translation of ming 命 into "scale" is Mair's. I believe that Mair's translation goes well with this musical context, while most commentators took it as "life" (e.g., Cheng Xuan-ying: 自然之性命).

23 Having consideration for the usage of “lín 林” (e.g., 大林, 林鐘) and “yùe 樂” in the pre-Qin musical discourse, “linyùe 林樂” is better to be read as musical instruments rather than music itself, although Ziporyn renders it into "a forest of sounds."

24 Here "yaoming 窈冥" means the place that is quietly secluded and mysteriously chaotic, but at the same time where everything comes out.

25 Most commentators and translators seem to render qing 情 into “shiqing 實情” (Mair: “circumstances"; Ziporyn: "uncontrived inclination of things") rather than emotion. Although it is arguable whether the author of Xiánchí had a concept corresponding to "emotion" in a modern sense, I put it as "genuine emotion", because this phrase follows heavenly joy and describes the way in which Chéng was moved.

26 As previously mentioned, "mìng 命" was rendered into "scale" in consideration of the context, but here, I prefer to translate it into "one's own destiny" in the sense of "what is to be conditioned" or "what is allotted", as other translators (Mair: "destiny"; Ziporyn: "their own mandates").

27 I follow Zyporyn to interpret “天樂” in double meaning because the word could read as tiānyùe and tiānlè at the same time.

28 The lord of Yen is regarded as another sage-emperor, Shénnóng (神農). 


\subsubsection{Reception of Chéng in the Final Movement}

You wanted to listen but had no way to go about it. That was why you felt confused. 汝欲聽之而無接焉, 而故惑也.

In the final movement, musical expression is freed from any regulation and restraint. Even every single sound does not remain unchanged as it was, but is constantly renewed with spontaneous flows, so now, music goes beyond description. Thereafter, the Daoist sages enter. The final movement is delivered directly through the sage himself.

\subsubsection{Closing Remark of Yellow Emperor}

Music begins with being terrified and because of this fear there is dread, and therefore one is stunned ${ }^{29}$. Then I follow it up by making it exhausting, and because of this weariness there is compliance. I end it all with confusion, and because of the confusion there is stupidity. Being stupid, you experience the Way, the Way that can carries you along, keeping you right there with it wherever you may go.

樂也者, 始於懼, 懼故崇; 吾又次之以怠, 忿故遁; 卒之於惑, 惑故愚; 愚故道, 道可載而與 之俱也.

\section{A Zhuangzian View on Sound and Music in Xiánchí Music}

On the basis of the reading so far, I would like to reexamine the implication of this story as a unique representation of music in the Chinese classical texts. Xiánchí music could be viewed as one of the most powerful versions of the Zhuangzian perspective on music in the pre-Qin period. The germinal ideas on music, metaphorically conceived in Inner Chapters, could have been developed in many other directions ${ }^{30}$. Above all, the author of Xiánchí music develops a significant position by focusing on sounds or Sound in the history of early Chinese musical discourse. This was originally one of the themes proposed in the Inner Chapter, where Zhuangzi suggested that music would not exist without sound. The fact that music is based on sound lets him appreciate even the piping of earth (dìlài 地籟) and, thus, all kinds of sounds blown from the earth are seen as music (lài 籟).

With its primary emphasis on sounds, the Xiánchí story attempts to delicately and carefully describes all kinds of differences and changes of musical sounds through all of the movements, but it is more intriguing that no single term " $y \bar{i} n$ " is used for this purpose in the whole text of Xiánchí music. The text avoids using the word "yīn", but rather describes Daoist ideal in music with only "shēng" and "yùe". Considering that the author of Xiánchí music is most probably conscious of the Book of Music, as mentioned before, and Zhuangzi was aware of the distinction between shēng, yīn and yù $e^{31}$, he might have intended to describe music in a different way, unlike the well-accepted hierarchical understanding of shèng, yīn and yùe in Confucian discourse ${ }^{32}$.

The Confucian distinction between shēng, yīn and yùe implies an equivocal attitude. The most well-known remark of the distinction appears in the first chapter of the Book of $\mathrm{Music}^{33}$, and it makes

29 I translate "suì 崇” into "stunned," whereas Watson "a curse," Mair "spooked" and Ziporyn "calamity."

30 For instance, "land music," "music of cosmic order" or "silence music" have often been noticed and discussed as possible Zhuangzian perspectives on music. As a less known, but significant Zhuangzian musical concern, the pursuit of "the source of sound" can be added: a special acoustic concern is displayed in Chapter 24 "Xuwugui" of the Zhuangzi, where it is asked what would be the lord of all kinds of sounds, namely "how to make 25 strings vibrate all at once". The Huainanzi took over this point, and the Lüshì Chünqiū achieved a compromise of Daoist and Confucian musical discourse on the basis of this acoustic concern.

31 We can find common usages of shēng, yīn and yuè and also intentionally twisted usages of them (“kòuyīn 犋音”, “huàshēng 化聲”, “yuèchūxū 樂出虛” in Chapter 2) in the Zhuangzi. See ([2], pp. 338-40).

32 As for the development of musical key terms in early China, see [14].

33 See the first lines in Chapter 1 of the Book of Music: "yinn (songs, music, all the modulations of the voice) arise from human mind/heart. The movement/all the affections of the human mind/heart are made so by external things. Human heart 
a distinction between human and animal with yīn and shēng and, then, goes further to distinguish common people's music and superior men's music with yīn and yùe. On the one hand, Confucian musical discourse repeatedly emphasizes yīn and human mind/heart, but on the other hand, it can never efface sheng from its hierarchy ${ }^{34}$. In other words, they acknowledge that yin is not the original source of music, but a critical point that makes shēng meaningful and valuable.

Instead of using the common distinction between shēng, yīn and yìe to reconstruct a Daoist counterpart or making a frontal attack against that distinction of Confucian hierarchy, Xiánchí music turns to devote all of its strength to "sound (shēng 聲)." By doing so, it shows that music comes into being due to sound, and at the same time, music completes itself through sound. Xiánchí music does not deny that sounds can be organized by a natural principle or by human consciousness, but it does not use the concept of yin to estrange sound from music. Instead, it replaces yinn with various kinds of combinations of sounds, moving in opposite directions.

Sound viz. shêng is not merely the building blocks of music, nor an imperfect representation of musical idea, but music in reality. Sound in Xiánchí music is the foundation of music and realization of music, as well. The presence of music in sound gives you a sense of belonging. Musical perfection moves you using sound. All of the touching moments and sympathies are conveyed and grasped through sound. Xiánchí music not only embraces the vocabularies of Confucian musical discourse, but surpasses the musical discourse of the time by pointing out that musical perfection is not achieved by musical idea or the morals of music imposed by superior men and sage kings, but by incessant attempts to transform musical expression and interactive experiences of a performer and listener and activated by sound, the final outcome of their cooperation.

Secondly, Xiánchí music is a well-balanced version of music in the sense that it has substantial contents of musical discourse, such as musical emotion, musical expression and structure, which, at their consummative stage, are eventually described as an experience of no-self or being with Dao. The relationship between musical reception and expression is described as an interactive process, rather than a one-way influence or identical pairs.

In the Confucian model, a listener is assumed to be a passive recipient otherwise liable to be attracted by indulgent music. Only superior men engage in a creative role, while common people should be guided by the classical and elegant music of sage kings. Additionally, the emotions that the listener is supposed to have as a result of the Confucian ideal music are not actually musical emotions, but definable emotions, such as pleasure, joy and reverence, which we can get from other objects. In Xiánchí music, however, a listener is a participant in aesthetic experience on the spot; that is to say, she or he is transforming the music and, at the same time, is transformed by the music, and she or she is perfecting the music and at the same time being perfected by the music. During the performance of Yellow Emperor, Chéng also performs his own task of self-effacement, which is the most significant musical experience. Since the one and only goal of musical perfection in Xiánchí music is losing oneself, in other words being united with Dao, musical perfection could not have been actualized without Chéng's transformation.

In a nutshell, musical expression and structure described in Xiánchí music converge on a quest for constant growth from the former framework in music. In this sense, Xiánchí music is a philosophy of music, which has "constant transformation" as its subject matter, rather than a manual book for illustrating "dos and don'ts" in music. The fear, weariness and confusion, which Chéng felt at each step, are not merely definable emotions, which exclude their antonyms, such as cheerfulness, excitement

is stimulated by things and then moved, and thus it forms in sound. Sounds respond to (are resonant with) each other, and thus changes are born. When the changes fit to a set of form (a regulation/a rule), we call it yīn". "Those who know

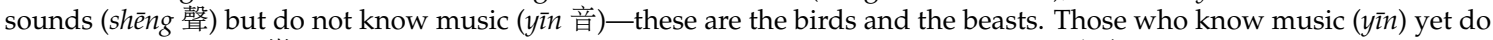
not know Music (yuè 樂)—these are the common masses. Only the superior man (jūnzi 君子) can know Music (yuè)." Refer to [12].

34 The effacement of shēng from the musical discourse is attempted in the Lüshì Chūnqiū. 
and clarity, but a kind of ineffable aesthetic feelings aroused and deepened by the variations of musical sounds at the gradually-intensified movements.

For example, Chéng's "fear" is not a kind of distress at the thought of danger to himself or something he cares about, but an aesthetic feeling aroused from his awareness of a musical progress being against his expectation, not because of clumsy and disappointing performance, but because of performance that is "constantly renewing its manner." His "weariness" is also not a result of repetitive performance of the same tunes, but an aesthetic feeling aroused from his compliance; that is to say, he can empty his preoccupation now and be moving along with all kinds of changes and, as a consequence, lose his previous fear. Lastly, his "confusion" is also not an episodic emotion that shows his incompetency of appreciating the music, but a description of his indescribable state, being united with Dao. His musical sensitivity is being enhanced, getting more delicate and accurate through each step.

\section{Concluding Remarks}

The story of Xiánchí music represents the nature of music as sound. As a mature version of Zhuangzian perspectives on music, it does not dwell on mere criticism of the Confucian hierarchical viewpoint, but tries to make an alternative way to understand music: how we engage in music; how music deepens our experience; how music remains powerful in ever-changing cultural contexts; and lastly, what music is. By doing so, it contributes an interactive model of musical experience and allows us to conceive of a bigger picture of music, which is not reduced to the notation of musical structure.

As suggested, a recipient or auditor is regarded as a necessary doer in musical experience in Xiánchí music, contrary to the Confucian model, where the recipient's character is to be molded by the morally-superior rulers' music. Without her or his aesthetic receptions, music would be nothing. A composer or player is not merely rendering his or her original ideas in musical notes or merely materializing the musical form into physical sounds, but is working out music in mutual cooperation with those receptions, unremittingly hoping not to remain complacent in conventional music.

The endorsement of sound in Xiánchí music sheds light on our understanding of the characteristics of Chinese musical discourse ${ }^{35}$ and probably on cross-cultural dialogue, as well. It cherishes the dynamics of musical experience that could be fully notated. Although sound becomes explicitly acknowledged in the Zhuangzian musical discourse and Confucian thinkers placed sound at a lower position in their hierarchical framework, they never excluded it from their theorization of music. In this regard, sound remains latent, even in Confucian theory of music, which presents a good contrast to Western development towards extraordinary emphasis on musical notation.

Acknowledgments: Comments by Franklin Perkins on the initial drafts of this article were deeply appreciated. The author would like to thank the anonymous reviewers for their helpful suggestions and the Humanities editors for their meticulous work.

Conflicts of Interest: The author declares no conflict of interest.

\section{References}

1. Liu, Xiao-Gan. Classifying the Zhuangzi Chapters. Ann Arbor: University of Michigan, 1994.

2. Park, So Jeong. "Musical Thought in the Zhuangzi-A Criticism of the Confucian Discourse on Ritual and Music." Dao: A Journal of Comparative Philosophy 12 (2013): 331-50. [CrossRef]

3. Guo, Qing-Fan (郭慶藩). Zhuangzi Jishi (莊子集釋, Collected Explanations on the Zhuangzi). Beijing: Zhonghua Shuju, 1989.

35 Its significance is not limited to theory of music in the sense that music was extensively discussed among early Chinese thinkers long time before the bloom of individual theories of art, such as literature, painting, and calligraphy in the era of Six Dynasties (220-589) and the musical framework by and large acted on the theorization of Chinese art. 
4. Yan, Ling-Feng (嚴靈峰). Wuqiubeizhai Zhuangzi Jicheng Chubian (無求備齋莊子集成初編, Compilation Commentaries on the Zhuangzi: the First Edition). Taipei: Yiwen Yinshuguan, 1972.

5. Yan, Ling-Feng. Wuqiubeizhai Zhuangzi Jicheng Xubian (無求備齊莊子集成續編, Compilation Commentaries on the Zhuangzi: the Sequel Edition). Taipei: Yiwen Yinshuguan, 1973.

6. Watson, Burton. The Complete Works of Chuang Tzu. New York and London: Columbia University Press, 1968.

7. Mair, Victor. Wandering on the Way: Early Taoist Tales and Parables of Chuang Tzu. New York: Bantam Books, 1994.

8. Ziporyn, Brook. Zhuangzi: The Essential Writings with Selections from Traditional Commentaries. Indianapolis and Cambridge: Hackett Publishing Company, 2009.

9. Cao, Chu-Ji. Zhuangzi Qianzhu (莊子淺注, A Shallow Commentary of the Zhuangzi). Beijing: Zhonghua Shuju, 1982.

10. Sun, Xi-Dan (孫希旦). Liji Jijie (禮記集解, Collected Interpretations on the Book of Ritual). Beijing: Zhonghua Shuju, 1988.

11. Cai, Zhong-De. Zhongguo Yinyue Meixueshi Ziliao Zhuyi (中國音樂美學史資料注譯, Commentaries and Translations of Materials for History of Music Aesthetics in China). Beijing: Renmin Yinyue Chubanshe, 1990.

12. Cook, Scott. "Yue Ji 樂記—Record of Music: Introduction, Translation, Notes, and Commentary." Asian Music 26 (1995): 1-96. [CrossRef]

13. Fukunaga, Mitsuji. Geishutzu Ronshu (藝術論集, Collection of Theories of Arts in China). Tokyo: Asahi Sinbunsya, 1971.

14. Park, So Jeong. "Sound, Tone, and Music in Early China: Philosophical Foundation for Chinese Sound Culture." In Inter-Culturality and Philosophic Discourse. Edited by Yolaine Escande, Vincent Shen and Chenyang Li. Newcastle: Cambridge Scholars Publishing, 2013.

(C) 2015 by the author; licensee MDPI, Basel, Switzerland. This article is an open access article distributed under the terms and conditions of the Creative Commons by Attribution (CC-BY) license (http:/ / creativecommons.org/licenses/by/4.0/). 